\title{
Moral sensitivity in Primary Health Care nurses
}

\author{
Sensibilidade moral de enfermeiros da Atenção Primária à Saúde \\ Sensibilidad moral de enfermeros de la Atención Primaria a la Salud
}

\section{Carlise Rigon Dalla Nora', Elma Lourdes Campos Pavone Zoboli", Margarida M Vieira' \\ ' Universidade Católica Portuguesa, Institute of Health Sciences. Porto, Portugal. \\ "Universidade de São Paulo, Nursing School, Department of Public Health Nursing. São Paulo, Brazil.}

\section{How to cite this article:}

Dalla Nora CR, Zoboli ELCP, Vieira MM. Moral sensitivity in Primary Health Care nurses. Rev Bras Enferm [Internet]. 2017;70(2):308-16. DOI: http://dx.doi.org/10.1590/0034-7167-2016-0453

\author{
Submission: 09-12-2016 Approval: 10-02-2016
}

\begin{abstract}
Objective: to characterize the profile and describe the moral sensitivity of primary health care nurses. Method: this is a quantitative, transversal, exploratory, descriptive study. The data were collected through the Moral Sensitivity Questionnaire translated and adapted to Brazil. 100 primary health care nurses participated, from Rio Grande do Sul, Brazil. The data collection took place during the months of March and July 2016, in an online form. The analysis of the data occurred through descriptive statistical analysis. Results: the nurses had an average moral sensitivity of 4.5 (out of 7 ). The dimensions with the greatest moral sensitivity were: interpersonal orientation, professional knowledge, moral conflict and moral meaning. Conclusion: the nurses of Rio Grande do Sul have a moderate moral sensitivity, which may contribute to a lower quality in Primary Health Care.
\end{abstract}

Descriptors: Moral Development; Nursing Ethics; Moral; Ethic; Nursing.

\section{RESUMO}

Objetivo: caracterizar o perfil e descrever a sensibilidade moral dos enfermeiros da Atenção Primária à Saúde. Método: tratase de um estudo quantitativo, transversal, exploratório descritivo. Os dados foram coletados por meio do Questionário de Sensibilidade Moral traduzido e adaptado para o Brasil. Participaram 100 enfermeiros da Atenção Primária à Saúde do Rio Grande do Sul, Brasil. A coleta de dados ocorreu durante os meses de março e julho de 2016, de forma online. A análise dos dados ocorreu por meio de análise estatística descritiva. Resultados: os enfermeiros apresentaram uma média de sensibilidade moral de 4,5 (de 7). As dimensões com maior sensibilidade moral foram: orientação interpessoal, conhecimento do profissional, conflito moral e significado moral. Conclusão: os enfermeiros do Rio Grande do Sul apresentam uma moderada sensibilidade moral, podendo isso contribuir para a realização de uma assistência de menor qualidade na Atenção Primária à Saúde.

Descritores: Desenvolvimento Moral; Ética de Enfermagem; Moral; Ética; Enfermagem.

\section{RESUMEN}

Objetivo: caracterizar el perfil y describir la sensibilidad moral de los enfermeros de la Atención Primaria a la Salud. Método: se trata de un estudio cuantitativo, transversal, exploratorio descriptivo. Los datos fueron recogidos por medio del Cuestionario de Sensibilidad Moral traducido y adaptado para Brasil. Participaron 100 enfermeros de la Atención Primaria a la Salud de Rio Grande do Sul, Brasil. La recogida de datos ocurrió durante los meses de marzo y julio de 2016, de forma en línea. El análisis de los datos ocurrió por medio de análisis estadística descriptiva. Resultados: los enfermeros presentaron un promedio de sensibilidad moral de 4,5 (de 7). Las dimensiones con mayor sensibilidad moral fueron: orientación interpersonal, conocimiento del profesional, conflicto moral y significado moral. Conclusión: los enfermeros de Rio Grande do Sul presentan una moderada sensibilidad moral, pudiendo eso aportar para la realización de una asistencia de menor cualidad en la Atención Primaria a la Salud.

Descriptores: Desarrollo Moral; Ética de Enfermería; Moral; Ética; Enfermería. 


\section{INTRODUCTION}

Primary Health Care $(\mathrm{PHC})$ is the structuring axis of the Unified Health System (SUS), since it coordinates the service network in order to guarantee the continuity and integrality of assistance at the various points of attention and care ${ }^{(1)}$. Nurses who work in this context face peculiar ethical problems that arise from the aspects, issues or ethical implications of everyday life and the production of services. Nurses need to be able to make ethical decisions when faced with ethical problems ${ }^{(2)}$. Study ${ }^{(3)}$ states that the higher the moral sensitivity of nurses the better is their ethics in clinical decision-making situations.

A precondition for responding to an ethical problem is to perceive it and, therefore, we speak of moral sensibility ${ }^{(4)}$. For this study, moral sensitivity is defined as the contextual and intuitive understanding of the patient's vulnerability situation, having an insight into the ethical consequences of decisions made on behalf of the patient ${ }^{(5)}$. The study ${ }^{(6)}$ broadened this concept and understood other dimensions beyond cognitive ability, including also sensations, feelings, moral knowledge and abilities.

Moral sensibility is therefore a personal attribute and a fundamental requisite for understanding nurses' ability to appropriately recognize, interpret, and respond to ethical issues in the patient's relationship, perceiving the potential influence of their actions on the patients' well-being ${ }^{(7)}$.

The ethical problems in the relations between the patients and the PHC professionals concern the limits of interference in style, in the people's way of life, when intervening in the health-disease process ${ }^{(8)}$. The ethical problems in this area are of high frequency and low intensity, characterized by a subtlety and the naturalization of violence in interpersonal relations that make it difficult for the professionals to perceive it.

Although this topic is of undeniable importance, there are few studies that deal with the moral sensitivity of nurses in PHC in Brazil. For the nurses to fulfill competently their functions and responsibilities, they must be prepared to face ethical problems ${ }^{(9)}$. Taking into account the set of challenges presented to the PHC nurse and knowing the importance of recognizing the moral sensitivity of nurses through their values, attitudes and knowledge, this study aims to characterize the profile and describe the moral sensitivity of Primary Health Care nurses.

\section{METHOD}

\section{Ethical aspects}

The study was approved on August 11, 2015 by the Research Ethics Committee of the University of São Paulo School of Nursing.

\section{Design, place of study and period}

This is a quantitative, cross-sectional, exploratory descriptive study ${ }^{(10)}$. Primary Health Care Nurses from Rio Grande do Sul, Brazil, were investigated from March to July 2016.

\section{Sample, inclusion and exclusion criteria}

The sample consisted of 100 nurses. As inclusion criteria, it was considered to be a nurse and to act in Primary Health Care. Nurses working in the hospital area were excluded.

\section{Study Protocol}

This study used the Moral Sensitivity Questionnaire (MSQ), elaborated from the qualitative analysis of the moral sensitivity of nurses from the psychiatric services of Sweden ${ }^{(11)}$. The 30 items of the questionnaire are distributed in 6 dimensions of moral sensitivity: 1 - interpersonal orientation, which focuses on building a relationship of trust with the patient and finds ways to respond to their needs; 2 - structuring of moral meaning, which refers to the process of reflection in the structuring of moral meaning for decisions and actions taken, even if they may limit the autonomy of the patient; 3 - benevolence, moral motivation to do the "good" or act in the best interest of the patient; 4 - autonomy, which refers to the strategies taken when the professional perceives the need to limit the autonomy of the patient, but is aware of the principle of autonomy; 5 - Experience of moral conflict, since for moral sensibility to be expressed in action, a potential or existing moral question must be previously identified and then recognize feelings, intuition and cognitive perception of a moral question about what "should" be done; and 6 - confidence in professional knowledge, which refers to the personal conviction that professional knowledge is necessary when dealing with moral issues ${ }^{(5,9)}$.

For the translation and adaptation of the MSQ into the Portuguese language of Brazil, the steps recommended by international studies were followed ${ }^{(12)}$. Initially, contact was made with the author of the original study ${ }^{(9)}$. The contact with the author of the scale was maintained throughout the translation stages of the instrument. Subsequently, the MSQ was translated into the Portuguese language of Brazil by two independent translators. Each translator did a translation, totaling two independent versions. To evaluate the two versions, a committee of seven experts was established to validate the content of the translated instrument. The Portuguese version was later translated into English (reverse translation). The versions (original, translation and reverse translation) were compared by the researchers of this study and the discrepancies were adjusted, giving rise to the final version. This stage of translation and adaptation is described in another article that is in the process of being published. The final version was sent to the author of the original questionnaire, which agreed with the translation and adaptation made to the Portuguese language of Brazil. After the author's agreement of the original study ${ }^{(11)}$, the questionnaire of moral sensitivity for the Portuguese language of Brazil was structured with 28 items. The questionnaire contains a likert response scale with 7 response options, being 1 - totally disagree and 7 - totally agree.

For data collection, the MSQ was made available online through the form available in Google Docs. In view of the difficulty of face-to-face access of researchers to PHC nurses distributed throughout the state, it was decided to disseminate online. The sampling technique was not random, since all the nurses enrolled in the Conselho Regional de Enfermagem no Rio Grande do Sul (COREN / RS) were invited to participate in the study. The online questionnaire is self-applied with issues of sociodemographic characterization and with the Brazilian version of the questionnaire of moral sensitivity. 


\section{Analysis of the results and statistics}

Data analysis was performed using the Statiscal Package for Social Sciences (SPSS), version 22 for Windows. In the descriptive analysis of the data, the absolute and relative frequencies, averages and standard deviations were calculated. For the descriptive analysis of the MSQ, the means and standard deviations were used. For the analysis of the MSQ dimensions in this study, the results of validation of the Brazilian Moral Sensitivity Questionnaire (MSQ-B), submitted for publication in another manuscript, were used. Therefore, the 27 MSQ-B items were analyzed, but the item 12 is not mentioned in the analysis, since it was eliminated in the previous validation phase.

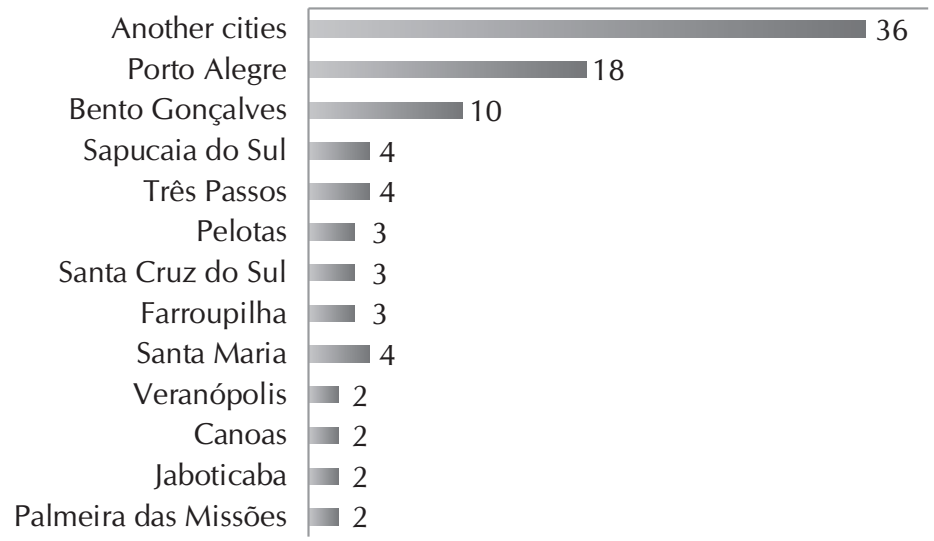

Figure 1 - City of nurses' performance in Rio Grande do Sul, Brazil

\section{RESULTS}

\section{Profile of PHC nurses}

From the 100 nurses who participated in the study, $91 \%$ were female, with the average age of 36.6 years (9.5). As for the marital status, $53 \%$ were married to a stable union. When questioned about receiving training in ethics or bioethics during graduation, $84 \%$ report that they received it. This data, coupled with some post-graduation training in ethics/bioethics in the last year, which was of $12 \%$, shows the predominance of nurses who have a certain degree of qualification, since $77 \%$ of the participants hold a specialization degree and $28 \%$ a master's degree. $57 \%$ of the nurses report that they needed counseling for ethical problems in their professional practice (Table 1).

When asked about their main activity in nursing, the majority $(52 \%)$ referred to work in care, 30\% in management and
$10 \%$ in education. Regarding the nurses' workplace, $86.9 \%$ reported working in the Basic Health Unit, Health Center, Health Post, Family Health Strategy Unit (FHS) / Family Health Support Center (FHSC). The cities with the highest participation of nurses from Rio Grande do Sul are described in Figure 1- (number of missing 7).

Regarding the duration of nurses' performance, the mean was 10.6 years (SD: 8.8 ). The results show that $79 \%$ of the nurses have been working for more than a year in $\mathrm{PHC}$, with a PHC mean duration of 7.3 years (PD: 6.5). Most nurses (82\%) report having only one employment relationship, being mainly statutory $(60 \%)$. The monthly income of nurses in relation to the minimum wage of $\mathrm{R} \$ 788.00$ is 5 to 7 salaries $(38.8 \%)$ (Table 1 ). As for the working day, $79 \%$ report that the weekly workload of the contract is $36-40$ hours.

Table 1 - General characteristics of primary health care nurses ( $N=100)$, Rio Grande do Sul, Brazil, 2016

\begin{tabular}{|c|c|c|c|c|}
\hline & $\mathbf{n}$ & $\%$ & Average & Standard deviation* \\
\hline \multicolumn{5}{|l|}{ Sex } \\
\hline Female & 91 & 91.0 & & \\
\hline Male & 9 & 9.0 & & \\
\hline Age & & & 36.6 & 9.5 \\
\hline \multicolumn{5}{|l|}{ Marital status } \\
\hline Married/ stable union & 53 & 53.0 & & \\
\hline Single & 38 & 38.0 & & \\
\hline Separated/divorced & 8 & 8.0 & & \\
\hline Widower (Widow) & 1 & 1.0 & & \\
\hline \multicolumn{5}{|l|}{ Education } \\
\hline Especialization & 77 & 77.0 & & \\
\hline Master's degree & 28 & 28.0 & & \\
\hline Residency & 14 & 14.0 & & \\
\hline Doctorate & 6 & 6.2 & & \\
\hline \multirow[t]{2}{*}{ Training in ethics or bioethics during graduation } & Yes & 84.0 & 84.0 & \\
\hline & No & 16.0 & 16.0 & \\
\hline
\end{tabular}




\begin{tabular}{|c|c|c|c|c|}
\hline & $\mathbf{n}$ & $\%$ & Average & Standard deviation* \\
\hline \multirow[t]{2}{*}{ Had any training in ethics or bioethics in the last year } & No & 88.0 & 88.0 & \\
\hline & Yes & 12.0 & 12.0 & \\
\hline \multirow[t]{2}{*}{ Needed advice to ethical problems in your practice } & Yes & 57.0 & 57.0 & \\
\hline & No & 43.0 & 43.0 & \\
\hline How long have you work as a nurse & & & 10.6 & 8.8 \\
\hline Years of working at $\mathrm{PHC}^{*}$ & & & 7.3 & 6.5 \\
\hline \multicolumn{5}{|l|}{ Time in the main workplace } \\
\hline More than one year & 79 & 79.0 & & \\
\hline Less than one year & 21 & 21.0 & & \\
\hline \multicolumn{5}{|l|}{ Type of bond } \\
\hline Statutory & 60 & 60.0 & & \\
\hline $\mathrm{CLT}^{* *}$ & 26 & 26.0 & & \\
\hline Temporary contract & 8 & 8.0 & & \\
\hline Self employed & 3 & 3.0 & & \\
\hline Others & 3 & 3.0 & & \\
\hline \multicolumn{5}{|l|}{ Monthly income ( $\mathrm{R} \$ 788.00)$} \\
\hline From 1 to 3 & 6 & 6.1 & & \\
\hline More than 3 to 5 & 27 & 27.0 & & \\
\hline More than 5 to 7 & 38 & 38.8 & & \\
\hline More than 7 to 10 & 21 & 21.4 & & \\
\hline More than 10 & 6 & 6.1 & & \\
\hline \multicolumn{5}{|l|}{ What is the main activity in nursing } \\
\hline Care & 52 & 52.0 & & \\
\hline Management & 30 & 30.0 & & \\
\hline Teaching & 10 & 10.0 & & \\
\hline Advisory & 3 & 3.0 & & \\
\hline Others & 5 & 5.0 & & \\
\hline \multicolumn{5}{|l|}{ How many employment relationships } \\
\hline 1 & 82 & 82.0 & & \\
\hline 2 & 17 & 17.0 & & \\
\hline 3 or more & 1 & 1.0 & & \\
\hline
\end{tabular}

Note: ${ }^{*}$ PHC $=$ Primary Health Care; $* * C L T=$ Consolidation of Labor Laws

The Moral Sensitivity Questionnaire in this study showed a total Cronbach's alpha of 0.847 (Table 2). The PHC nurses from Rio Grande do Sul gave an average score of 4.5 (out of 7) for their moral sensitivity.

As the 7-point response scale was used, (1 strongly disagree and 7 strongly agree) to explore the degree of agreement with moral sensitivity, high scores indicate a higher degree of moral sensitivity.

The items of higher average, that is, that show greater moral sensitivity in the questionnaire, were: item $1(5,7)$ (It is my responsibility as a nurse to know the patient in its entirety); Item $6(5,7)$ (When I have to make difficult decisions for the patient, it is important to always be honest with him / her); Item $7(5,7)$ (I believe that good nursing care includes respect for the patient's decision); and item 27 (5.4)) (As a nurse, I must always know how each of my patients should be respectfully approached) (Table 2).
Items $24(2,7)$ (Sometimes there is good reason to threaten a patient with an injection when oral medication is refused) and $8(2,8)$. (If a patient does not accept their illness, there is little I can do for him / her), were the ones who scored the lowest when the averages were observed, that is, items that demonstrate a lower moral sensitivity of the nurses (Table 2).

Moral sensibility was subdivided into four dimensions, according to MSQ-B validation. For the PHC nurses from Rio Grande do Sul, the dimension of interpersonal orientation presented the items that indicated greater moral sensitivity (mean 4.79, SD 1.17), Cronbach's alpha 0.837; professional knowledge (mean 3.84, SD 1.23), Cronbach's alpha 0.748; moral conflict (mean 4.22, SD 1.47), Cronbach's alpha 0.724 ; and the moral meaning (mean 4.81, SD 1.58) Cronbach's alpha 0.633 (Table 2). 
Table 2 - Descriptive analysis and internal consistency of the MSQ-B of nurses of Primary Health Care (N = 100), Rio Grande do Sul, Brazil, 2016

$\begin{array}{ccc}4.79 & 1.17 & 0.837 \\ 5.7 & 2.2 & \\ 5.7 & 2.3 & \\ 5.7 & 2.2 & \\ 2.8 & 2.1 & \\ 5.1 & 1.8 & \\ 4.8 & 1.6 & \\ 4.1 & 1.9 & \\ 5.1 & 2.1 & \\ 4.9 & 2.1 & \\ 5.1 & 2.1 & \\ 2.7 & 2.3 & \\ 5.2 & 1.9 & \\ 5.4 & 2.3 & \\ 5.0 & 2.1 & \\ 3.84 & 1.23 & 0.748 \\ 3.7 & 1.9 & \\ 4.1 & 1.8 & \\ 3.7 & 2.0 & \\ 3.8 & 1.6 & \\ 4.1 & 1.8 & \\ 3.7 & 1.9 & \\ 4.22 & 1.47 & 0.724 \\ 4.6 & 2.1 & \\ 4.5 & 1.9 & \\ 3.7 & 1.9 & \\ 4.1 & 2.0 & \\ 4.81 & 1.58 & 0.633 \\ 5.2 & 2.3 & \\ 4.7 & 1.9 & \\ 4.5 & 2.0 & \\ 4.49 & 0.90 & 0.847\end{array}$

1 - It is my responsibility as a nurse to know the patient as a whole.

6 -When I have to make difficult decisions for the patient, it is important to always be honest with him / her.

7 - I believe that good nursing care includes respect for the patient's decision.

8 - If a patient does not accept his illness, there is little I can do for him / her

10 - I believe it is important to have firm principles to care for certain patients.

13 - The most important thing in my nursing practice is my relationship with patients.

18 - Above all, it is the patients' reactions that show me that I have made the right decision.

19 - I often think about my values and norms that can influence my reactions.

21- I believe that good nursing care includes participation of the patient, even of those with severe mental disorders.

23 - I find it difficult to provide good nursing care against the patient's wishes.

24 -Sometimes there is good reason to threaten a patient with an injection when oral medication is refused.

25 - In situations where it is difficult to know what is right, I consult my colleagues on what to do.

27 - As a nurse, I must always know how each of my patients should be respectfully addressed.

28 - I find meaning in my activity, even when I cannot help a patient to be aware of his illness.

Professional Knowledge

4 - When I need to make a decision against the patient's will, I do according to my opinion about what is good care.

15 - I always base my actions on nursing knowledge of what is the best treatment, even if the patient protests.

16 - I believe that good nursing care will often include making the decision for the patient.

17- When I'm unsure, I mostly rely on the doctors' knowledge about patients.

20 - My experience is more useful than theory in situations where it is difficult to know what is ethically correct.

26 - I rely mostly on my intuition when I have to make a difficult decision for a patient.

Moral conflict

9 -I am often confronted with situations where I encounter conflicts over how to approach the patient.

11 - I often face situations in which it is difficult to know which action is ethically correct for a particular patient.

14 - I often face situations where I find it difficult to allow the patient to make their own decision.

22 - I often come across difficult situations where I have to make decisions without the patient's participation.

Moral meaning

2 - My work would not make sense if I never saw improvement in my patients.

3- It is important that I get a positive response from the patient in everything I do.

5 - I lost the patient's confidence, I would feel that my work would not make sense.

Total

$0.90-0.847$

Note: ${ }^{*}$ The average items of the scale was calculated by Likert scale values of 7 points; ${ }^{*} S D=$ Standard Deviation

\section{DISCUSSION}

Regarding the profile of nurses working in $\mathrm{PHC}$, the predominance of the female gender $(91 \%)$ was verified, corresponding to what has already been verified in the composition of the nursing workforce. Data from the Conselho Regional de Enfermagem do Estado do Rio Grande do Sul -COREN / RS ${ }^{(13)}$ show that of the total number of 22.410 nurses registered in COREN / RS, 20.146 (89.8\%) are female and $2.264(10.1 \%)$ male. The results of this study demonstrate that nursing is a predominantly female profession.

As the mean age was 36.6 ( $\mathrm{SD}=9.5)$, there was a predominantly young population. A research published on the nursing profile in Santa Catarina (SC) ${ }^{(14)}$ corroborates these results and reports that $63.9 \%$ of the nursing team is aged 40 years or less. Regarding the time of performance as a nurse, the mean in this study was $10.6(\mathrm{SD}=8.8)$ and the duration of the PHC was 7.3 (SD = 6.5), which indicates 
that the nurses have some professional experience in the researched area.

Another data related to the profile that is worth highlighting is that $77 \%$ of $\mathrm{PHC}$ nurses have specialization and $84 \%$ had ethics / bioethics training during graduation. As the ethical aspect is inserted in the National Curricular Guidelines of the Undergraduate Nursing Course ${ }^{(15)}$, there is an appreciation of the ethical and humanistic dimensions, developing in nursing students attitudes and values oriented towards citizenship and solidarity.

The results show that few nurses $(12 \%)$ had any type of ethical or bioethical training in the last year. This is a disturbing fact, because it is important that nurses have spaces for ethical discussion, with moments of sharing, exchange of experiences and discussion of ethical problems that may occur in services ${ }^{(16)}$. As it is possible to show in the results, $57 \%$ of $\mathrm{PHC}$ nurses already needed counseling for ethical problems in their professional practice, that is, most professionals have experienced some type of ethical problem in their practice. The literature corroborates this finding by describing that the main ethical problems of nurses in $\mathrm{PHC}$ occur in the relationship with patients, in the relationship between the team and the management of the health service ${ }^{(16)}$.

The primary place of work for PHC nurses is the Basic Health Unit, Health Center, Health Office, ESF / NASF Unit, as these are the units responsible for being the gateway to health services. There is evidence that health systems based on PHC are more appropriate because they are organized based on the health needs of the population. They are more efficient because they present lower costs and reduce more expensive procedures, and they have more quality because they place emphasis on health promotion and disease prevention ${ }^{(17)}$.

The type of bond of the nurses of the PHC is statutory $(60 \%)$, with monthly income of 5 to 7 salaries (38.8\%). The PHC expects nurses to stay in the same place of work as long as possible, since it is essential that a bond be established with the patient, family and the entire community. The bond makes possible the extension of the relational bonds, developing affections and potentializing the therapeutic process ${ }^{(18)}$. Having a suitable salary for the nurse makes the professional need not look for a second job to meet their income. Possibly because of this, $82 \%$ of the nurses had only one employment relationship. These data corroborate with that evidenced in studies carried out by the Federal Nursing Council ${ }^{(19)}$, which indicates that the majority of nurses $(63 \%)$ have only one activity / work. Data from COREN / SC ${ }^{(14)}$ also indicate that $67.95 \%$ of nurses have only one employment relationship. Still, the PHC nurses indicate that the weekly workload is $36-40$ hours $(79 \%)$. Data from COREN / SC (14) also coincide with this reality, where $77.5 \%$ work from 31 to more than 80 hours per week.

The study measured the moral sensitivity of PHC nurses, resulting in an average of 4.5 out of 7 , considered moderate, which is in agreement with other studies ${ }^{(20-22)}$. This result is lower than the average of the nursing students $(5.03, \mathrm{SD}=$ 0.43 ) (2) and the Korean nurses (5.14, SD $=0.55^{(7)}$.

Regarding the reliability of the instrument, this study presented a Cronbach's alpha coefficient of 0.847 , higher than that found in the original scale $(0.78)^{(9)}$. Our result was similar to the study ${ }^{(7)}$ that reported an alpha Of 0.85 . Minor coefficients were reported in the studies that used MSQ as a source of data collection, as evidenced: the Chinese version of MSQ had an alpha of $0.82^{(23)}$; nurses from Iran $0.78^{(20)}$; Korean nurses $0.76^{(24)}$ and alpha of 0.73 with nursing students ${ }^{(2)}$.

The study ${ }^{(24)}$ made with Korean nurses in a hospital environment presents the same classification (hierarchy) of the items found in the nurses of the PHC in Rio Grande do Sul. It is my responsibility as a nurse to know the patient as a whole, 6 (5.97) (When I have to make difficult decisions for the patient, it is important to always be honest with him / her) and 27 (5.88) (As a nurse, I must always know how each of my patients should be respectfully approached) were the highest mean of moral sensitivity. However item 24 (4.14) (Sometimes there is good reason to threaten a patient with an injection when oral medication is refused) and item 8 (3.36). (If a patient does not accept their illness, there is Little that I can do for him / her) were the ones with the lowest average moral sensitivity. The same was true of the study ${ }^{(7)}$ in which the item with the highest moral sensitivity was 1 (6.07) and 27 (5.95), while the items with the lowest sensitivity were 8 (3.86).

The difference in relation to the studies cited above is that, in this research, item 7 (5.7) (I believe that good nursing care includes respect for the patient's decision) was the one that presented the highest mean of moral sensitivity. This is probably due to the fact that the National Policy on Primary Care has as its basis and guidelines to stimulate the participation of users as a way to increase their autonomy and capacity in the construction of health care for people and communities in the territory ${ }^{(25)}$.

When moral sensitivity was divided into four dimensions, the one of greatest moral sensitivity was the interpersonal orientation (Alpha 0.83 and mean of 4.79). Study ${ }^{7}$ also presented a higher mean (5.68) in this category that was named by the authors of "patient-centered nursing". In the same way, study ${ }^{(21)}$ describes the category entitled "patient-oriented care" as the one with the greatest influence on the moral sensitivity of nurses.

It can be said that the nurses of Rio Grande do Sul refer to greater moral sensitivity in the dimension of interpersonal orientation, which focuses on building a relationship of trust with the patient, seeking to find ways to respond to their individual needs ${ }^{(9)}$. In PHC, for good nursing care, it is essential to establish a relationship of trust and bond with the patient. The study ${ }^{(26)}$ states that PHC can be defined as the level of a health services system that enables the achievement of responses to all the needs and problems of the community, as it produces health care services and actions in practically all conditions . Nurses in this area need to incorporate health promotion as a strategy for social and political transformation of community health, promoting the broad concept of health and integral care, responding to the needs of patients and to the principles of the Unified Health System ${ }^{(25)}$.

In this dimension, there were also items referring to the patient's autonomy and the strategies taken when the nurse perceives the need for limitation, but is aware or aware of the autonomy principle ${ }^{(9)}$. An extreme way to limit patient autonomy is to use an injection to force the patient to take medication. This, however, can be interpreted in the sense that sometimes professionals feel obliged to "circumvent" the rules, aiming at the best care for the patient. This was described in a study ${ }^{(27)}$ with psychiatric nurses in the care of the mentally ill patient, 
where in acute situations it was necessary to transcend the rules and regulations, if this was in the patient's best interest.

The knowledge of the professional was the second dimension that has an influence on the moral sensitivity of nurses, and this knowledge is fundamental when dealing with moral issues $^{(28)}$. The study ${ }^{(16)}$ describes that it is necessary to maintain permanent educational processes in ethics, developing practical skills, competence and moral sensitivity to lead the nurse to reflection, discussions and prudent and responsible resolution of ethical problems. In this context, it is essential to encourage not only nursing students, but also PHC nurses, to exercise ethical judgment so that they can develop the capacity to reflect and question decisions about care, so as not to obscure the ethical dimension of Clinical decisions.

In this context, nurses who are systematically educated to conduct ethical judgments will be better prepared to deal with unexpected ethical problems that occur during nursing care ${ }^{(29)}$. The ethical responsibility of nurses is often greater than their technical responsibility and, therefore, they are expected to be sensitive to the ethical problems of care $^{(30)}$.

The moral conflict and moral meaning dimensions had a reduced moral sensitivity referred by the nurses of Rio Grande do Sul. The moral conflict perceived by PHC professionals is described in the literature in different studies ${ }^{(16,31)}$. The SUS has been following a difficult process of consolidation, mainly in what concerns the financing, being urgent the need to rethink its organization in the sustainability of the current conformation. In this sense, conflicts arise in this scenario, creating tensions that emanate from the organization of the health network, passing the team and the patient ${ }^{(31)}$.

The moral meaning dimension is related to the fact that the nurse is able to recognize a moral situation, that is, to distinguish a moral situation from a non-moral one, in the professional-patient relationship. The nurse with reduced moral sensitivity can recognize an ethical problem without assigning little or no importance to this problem ${ }^{(32)}$. Ethical problems can occur in common situations of everyday practice and thus go unnoticed when the nurse's moral sensitivity is diminished ${ }^{(3)}$. According to a study ${ }^{(5)}$, nurses' sensitivity is not only a matter of feeling, that is, relying on their own emotions to identify an ethical problem, but a personal component acquired by personal experience to perceive the moral meaning in situation.

\section{Limitations of the Study}

It can be observed that this is a cross-sectional study based on a convenience sample limited to a specific region. Therefore, the results cannot be generalized. The reduced number of nurses may have interfered with the results. There is a need for more research involving PHC nurses in different regions of Brazil in the future.

\section{Contributions to the area of nursing, public health or pub- lic policy}

The results of this study generate contributions to the nurses to the extent that they need to assess and enhance their moral sensitivity. They also contribute to the management of $\mathrm{PHC}$ services that need to encourage the creation of spaces for discussion and attention to ethical problems for the training institutions that need to provide coherent educational strategies capable of stimulating the moral development of nursing students and implications for patients, Because when they are attended by nurses with a decreased moral sensitivity it is possible that they have a lower quality care.

\section{CONCLUSION}

The findings made it possible to characterize the profile and identify the moral sensitivity of the PHC nurses from Rio Grande do Sul. It was concluded that the PHC nurses from Rio Grande do Sul had moderate moral sensitivity. This study allowed to indicate the most important dimensions in the moral sensitivity of PHC nurses, being interpersonal orientation, professional knowledge, moral conflict and moral meaning, respectively. The novelty in the context of Brazilian PHC is highlighted in the results of this study regarding the moral sensitivity of nurses. It is only an initial study and is intended to be a motivator for further research. In a forthcoming publication, the psychometric properties of the questionnaire will be disclosed, in order to provide a valid tool to measure the moral sensitivity of nurses in Brazil.

Therefore, it is recommended that nurses promote their moral sensibility through educational programs that emphasize how to deal with ethical issues in PHC, which can result in moral distress. Educational activities are a way of cultivating the development of moral sensibility

\section{FOMENTATION}

To the Coordination of Improvement of Higher Education Personnel (CAPES), thanks are extended for the scholarship granted by the Sciences without Borders Program in the form of full doctorate abroad, BEX process: 2762-13-7, and to the Conselho Regional de Enfermagem do Rio Grande do Sul (COREN / $\mathrm{RS})$, for their collaboration in the dissemination of the research.

\section{REFERENCES}

1. Rodrigues LBB, Silva PCS, Peruhype RC, Palha PF, Popolin MP, Crispim JA, et al. [Primary Health Care in the coordination of health care networks:an integrative review]. Ciênc Saúde Colet[Internet]. 2014[cited 2016 Sep 12];19(2):343-52. Available from: http://www. scielo.br/pdf/csc/v19n2/1413-8123-csc-19-02-00343.pdf Portuguese.

2. Sahin S, Iyigun E, Acikel C. Validity and Reliability of a Turkish Version of the Modified Moral Sensitivity Questionnaire for Student Nurses. Ethics Behav[Internet]. 2015 [cited 2016 Jun 5];25(4):351-9. Available from: http://www.tandfonline.com/doi/abs/10.1080/10 508422.2014 .948955 
3. Robichaux C. Developing ethical skills: from sensitivity to action. Crit Care Nurs[Internet]. 2012[cited 2016 Feb 8];32(2):65-72. Available from: http://ccn.aacnjournals.org/content/32/2/65.full.pdf + html

4. Trobec I, Starcic AI. Developing nursing ethical competences online versus in the traditional classroom. Nurs Ethics[Internet]. 2015[cited 2016 Set 15];22(3):352-66. Available from: http://ccn.aacnjournals.org/content/32/2/65.full.pdf + html

5. Lützén K, Evertzon M, Nordin C. Moral sensitivity in psychiatric practice. Nurs Ethics[Internet]. 1997[cited 2016 Set 8];4(6):472-82. Available from: http://nej.sagepub.com/content/4/6/472.long

6. Lützén K, Dahlqvist V, Eriksson S, Norberg A. Developing the concept of moral sensitivity in health care practice. Nurs Ethics[Internet]. 2006[cited 2016 Set 3];13(2):187-96. Available from: http://nej.sagepub.com/content/13/2/187.long

7. Kim YS, Kang SW, Ahn JA. Moral sensitivity relating to the application of the code of ethics. Nurs Ethics[Internet]. 2013 [cited 2016 Jan 23];20(4):470-8. Available from: http://nej.sagepub.com/content/20/4/470.long

8. Junges JR. Bioética Sanitarista: desafios éticos da saúde coletiva. São Paulo: Loyola; 2014.

9. Lützén K, Nordström G, Evertzon M. Moral sensitivity in nursing practice. Scand J Caring Sci[Internet]. 1995[cited 2016 Jun 15];9(3):1318. Available from: http://onlinelibrary.wiley.com/doi/10.1111/j.1471-6712.1995.tb00403.x/epdf

10. Pasquali L. Psicometria: teoria dos testes na psicologia e educação. Petrópolis: Vozes; 2003.

11. Lützén K. Moral sensitivity, a study of subjective aspects of moral decision making in nursing practice. Stockholm: Karolinska Institute; 1993.

12. Guillemin F, Bombardier C, Beaton D. Cross-cultural adaptation of health-related quality of life measures: literature review and proposed guidelines. J Clin Epidemiol[Internet]. 1993[cited 2016 Sep 15];46(12):1417-32. Available from: http://www.jclinepi.com/ article/0895-4356(93)90142-N/pdf

13. Brasil. Conselho Regional de Enfermagem do Estado do Rio Grande do Sul. Departamento de Comunicação Institucional do Coren-RS[Internet]. 2015[cited 2016 Jul 21]. Available from: http://www.portalcoren-rs.gov.br

14. Brasil. Conselho Regional de Enfermagem do Estado de Santa Catarina. Pesquisa Perfil da Enfermagem demonstra em Santa Catarina nível de escolaridade acima do exigido, baixos salários e jornada elevada. [Internet]. 2015[Cited 2016 Jul 25]. Available from: http:// www.corensc.gov.br/2015/08/10/pesquisa-perfil-da-enfermagem-demonstra-em-santa-catarina-nivel-de-escolaridade-acima-do-exigido-baixos-salarios-e-jornada-elevada/.

15. Ministério da Educação (Brasil). Parecer CNE/CES n ${ }^{\circ}$. 1133, de 07 agosto de 2001. Diretrizes curriculares nacionais dos cursos de graduação em enfermagem, medicina e nutrição. Diário Oficial da União[Internet]. 2001[Cited 2016 Jul 25]. Available from: http://portal.mec.gov.br/dmdocuments/ces1133.pdf

16. Dalla Nora CR, Zoboli ELCP, Vieira M. Ethical problems experienced by nurses in primary health care: integrative literature review. Rev Gaúcha Enferm[Internet]. 2015[cited 2016 Sep 12];36(1):112-21. Available from: http://www.scielo.br/pdf/rgenf/v36n1/1983-1447rgenf-36-01-00112.pdf

17. Oliveira MAC, Pereira IC. Atributos essenciais da Atenção Primária e a Estratégia Saúde da Família. Rev Bras Enferm[Internet]. 2013[cited 2016 Sep 12];66(spe):158-64. Available from: http://www.scielo.br/pdf/reben/v66nspe/v66nspea20.pdf

18. Assis MMA, Nascimento MAA, Pereira MJB, Cerqueira EM. Comprehensive health care: dilemmas and challenges in nursing. Rev Bras Enferm[Internet]. 2015[cited 2016 Sep 12];68(2):333-8. Available from: http://www.scielo.br/pdf/reben/v68n2/en_0034-7167-reben-68-02-0333.pdf.

19. Brasil. Conselho Federal de Enfermagem. Pesquisa inédita traça perfil da enfermagem. [Internet]. 2015[Cited 2016 May 6]. Available from: http://www.cofen.gov.br/pesquisa-inedita-traca-perfil-da-enfermagem 31258.html/print/

20. Jaafarpour M, Khani A. Evaluation of the nurses' job satisfaction, and its association with their moral sensitivities and well-being. J Clin Diagn Res[Internet]. 2012[cited 2016 Set 6];6(10):1761-4. Available from: http://europepmc.org/backend/ptpmcrender.fcgi?accid=P MC3552222\&blobtype $=$ pdf

21. Borhani F, Abbaszadeh A, Mohamadi E, Ghasemi E, Hoseinabad-Farahani MJ. Moral sensitivity and moral distress in Iranian critical care nurses. Nurs Ethics[Internet]. 2015[cited 2016 Out 20];28:1-9. Available from: http://nej.sagepub.com/content/early/2015/09/24/0969733015604700.long

22. Elzadi Al, Khademi Z, Asadi Noughabi F, et al. The correlation of moral sensitivity of critical care nurses with their caring behavior. Iran J Med Eth[Internet]. 2013[cited 2016 Out 20];6(2):43-56. Available from: http://ijme.tums.ac.ir/browse. php?a_id $=5014 \&$ sid $=1 \&$ slc_lang $=$ en

23. Huang F, Yang Q, Zhang J, Khoshnood K, Zhang JP. Chinese nurses' perceived barriers and facilitators of ethical sensitivity. Nurs Ethics[Internet] 2015[cited 2016 Out 20];29:1-16. Available from: http://nej.sagepub.com/content/23/5/507.long

24. Han S, Kim J, Kim Y, Ahn S. Validation of a Korean version of the Moral Sensitivity Questionnaire. Nurs Ethics[Internet]. 2010[Cited 2016 Fev 6];17(1):99-105. Available from: http://nej.sagepub.com/content/17/1/99.long

25. Brasil. Ministério da Saúde, Secretaria de Atenção à Saúde, Departamento de Atenção Básica. Política Nacional de Atenção Básica[Internet]. Brasília (DF): Ministério da Saúde; 2012[cited 2016 Jul 6]. Available from: http://189.28.128.100/dab/docs/publicacoes/Geral/pnab.pdf 
26. Mascarenhas NB, Melo CMM, Fagundes NC. Production of knowledge on health promotion and nurse's practice in Primary Health Care. Rev Bras Enferm[Internet]. 2012[cited 2016 Sep 3];65(6):991-9. Available from: http://www.scielo.br/pdf/reben/ v68n2/en_0034-7167-reben-68-02-0333.pdf

27. Lützén K. Moral sensing and ideological conflict: aspects of the therapeutic relationship in psychiatric nursing. Scand J Caring Sci[Internet]. 1990[cited 2016 Sep 3];4(2):69-76. Available from: http://onlinelibrary.wiley.com/doi/10.1111/j.1471-6712.1990. tb00048.x/epdf

28. Lützén K, Blom T, Ewalds-Kvist B, Winch S. Moral stress, moral climate and moral sensitivity among psychiatric professionals. Nurs Ethics[Internet]; 2010[cited 2016 Sep 3];17(2):213-24. Available from: http://nej.sagepub.com/content/17/2/213.long

29. Ramos FRS, Brehmer LC, Vargas MA, Trombetta AP, Silveira LR, Drago L. Ethical conflicts and the process of reflection in undergraduate nursing students in Brazil. Nurs Ethics[Internet]. 2015[cited 2016 Sep 15];22(4):428-39. Available from: http://nej.sagepub.com/content/22/4/428.long

30. Kim YS, Park JW, You MA, Seo YS, Han SS. Sensitivity to ethical issues confronted by Korean hospital staff nurses. Nurs Ethics[Internet]. 2005[cited 2016 Sep 3];12(6):595-605. Available from: http://nej.sagepub.com/content/12/6/595.long

31. Vidal Sv, Motta Lcs; Gomes Ap, Siqueira-Batista R. [Bioethical Issues in the Family Health Strategy: relevant reflections]. Rev Bioét[Internet]. 2014[cited 2016 Sep 10];22(2):347-57. Available from: http://www.scielo.br/pdf/bioet/v22n2/17.pdf Portuguese.

32. Weaver, K. Ethical sensitivity: state of knowledge and needs for further research. Nurs Ethics[Internet]. 2007[cited 2016 Sep 15];14(2):141-55. Available from: http://nej.sagepub.com/content/14/2/141.long 